\title{
Rhynchotechum nirijuliense (Gesneriaceae), a new species from Northeast India
}

\author{
M. Taram ${ }^{1} \&$ D. Borah ${ }^{1,2}$ \\ ${ }^{1}$ Department of Botany, Rajiv Gandhi University, Rono Hills, \\ Doimukh 791112, Arunachal Pradesh, India \\ ${ }^{2}$ Department of Botany, Goalpara College, Goalpara \\ 783101, Assam, India \\ dipankar.borah@rgu.ac.in
}

\begin{abstract}
A new species of Rhynchotechum (Gesneriaceae), Rhynchotechum nirijuliense Taram \& D.Borah, is described from Nirijuli of Papum Pare district in Arunachal Pradesh, Northeast India. The new species is compared to Rhynchotechum ellipticum and $R$. calycinum. A detailed description, colour photographs and notes on the distribution and ecology of the new species are provided.
\end{abstract}

Keywords. Eastern Himalaya, Flora of Arunachal Pradesh, Rhynchotechum ellipticum

\section{Introduction}

Rhynchotechum Blume in the Gesneriaceae comprises 16 species distributed across India to China, Japan, the Philippines, the Malay Peninsula, Sumatra and Papua New Guinea (Anderson \& Middleton, 2013; Möller et al., 2017; Roy et al., 2019). It has opposite or alternate leaves, cymose inflorescences with small white to pink flowers and characteristic white indehiscent berries (Anderson \& Middleton, 2013). The plants are mostly found in tropical forests, preferring moist shady places near streams and river banks (Anderson \& Middleton, 2013). The genus is also known to have ethnobotanical importance and is used by many tribes residing in Northeast India (Kayang, 2007; Ozah \& Borah, 2018). In India, a total of nine species are found: R. alternifolium C.B.Clarke, $R$. calycinum C.B.Clarke, $R$. ellipticum (Wall. ex D.Dietr.) A.DC., $R$. gracile B.M.Anderson, $R$. hookeri (C.B.Clarke) B.M.Anderson, R. obovatum (Griff.) B.L.Burtt, R. parviflorum Blume, R. permolle (Nees) B.L.Burtt and R. vestitum Wall. ex C.B.Clarke (Anderson \& Middleton, 2013; Sinha \& Datta, 2016; Möller et al., 2017; Taram et al., 2020).

During ongoing floristic exploration of the tropical forests of Nirijuli of Papum Pare district, Arunachal Pradesh, India, the authors collected some interesting specimens of a Rhynchotechum. On critical examination of the specimens and comparison with specimens present in ARUN, ASSAM, K and PE, and after perusing the relevant literature, it was found to differ from known taxa and is hence described here as a new species. 
Rhynchotechum nirijuliense Taram \& D.Borah, sp. nov.

Rhynchotechum nirijuliense is most similar to $R$. ellipticum in plant height, arrangement and shape of leaves, young parts woolly pubescent, reduced or absent peduncle and narrowly triangular calyx lobes, and to $R$. calycinum in overall leaf shape, denticulate lamina margin, inflorescence length and villous branches, but differs from both in the generally shorter petiole, more numerous secondary veins, more villous calyx lobes, longer style and larger berries (see Table 1). - TYPE: India, Arunachal Pradesh, Papum

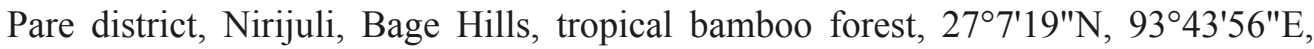
166 m, 1 May 2019, M. Taram \& D. Borah 0157 (holotype CAL; isotypes ASSAM, ARUN, E). (Fig. 1)

Stems to $2 \mathrm{~m}$ tall, 1-1.8 cm diameter, internodes 4-16 cm. Leaves opposite; almost sessile, petiole if present $0.5-1.2 \mathrm{~cm}$ long; blade broadly lanceolate to obovate, $(28-) 30-38(-45) \times(11.5-) 12-16(-19.4) \mathrm{cm}$, apex acute to shortly acuminate, base narrowly cuneate, margin undulate, denticulate, teeth to $1 \mathrm{~mm}$ long, lateral veins (26)27-32(-39) on each side, adaxially green, glabrous, abaxially pale green, villous along veins, later glabrescent, young ones densely villous on both surfaces. Inflorescence axillary, including from nodes of fallen leaves; peduncle reduced or absent, branches 4-6 from each node, oppositely arranged 2-3 from each side, up to $6.5 \mathrm{~cm}$ long, twice to thrice branched, first branch 1-1.5 cm long, second branch 1-1.5 cm long, third branch $0.3-0.5 \mathrm{~cm}$ long, axes densely villous; bracts ovate to ovate lanceolate, navicular, undulate, deeply grooved along the midvein, paired, each at the axil of the first branches, 10-12 × 4-6 mm; bracteoles paired, one per branch, pale pink, ovate, entire, membranous, midvein prominent, $1-1.2 \times 0.8-1 \mathrm{~cm}$; pedicels $0.3-1.5$ $\mathrm{cm}$ long, silky villous. Calyx divided to near the base, tube 1-2 $\mathrm{mm}$ long, lobes ovate lanceolate, with broadly acuminate apices, 7-10 $\times 1.8-2.2 \mathrm{~mm}$, equal to or longer than the corolla, villous outside, glabrous inside. Corolla pink, exterior glabrous; tube 2-3 mm long; upper lip 5-7 mm, upper lobes orbicular, 2-3 $\times 5-6 \mathrm{~mm}$, apices rounded to obtuse; lower lip 8-10 mm, lower lobes ovate oblong, 3-5 × 3-4 mm, apices obtuse to rounded. Stamens inserted near the base of the corolla tube; filaments c. $1 \mathrm{~mm}$ long; anthers c. $1.5 \mathrm{~mm}$ diameter, glabrous; staminode inconspicuous. Ovary ovoid, 1-1.5 $\times$ 1-1.2 mm, glabrous; style 8-9 mm long; stigma apex globose/rounded to truncate. Fruit fleshy, white, ovoid, 1.2-1.5 × 0.7-0.9 cm, glabrous.

Distribution and ecology. Rhynchotechum nirijuliense is known from a single locality, the Bage Hills of Nirijuli. It occurs in damp and shady areas alongside streams and grows in association with Bambusa sp. (Poaceae), Begonia aborensis Dunn (Begoniaceae), Impatiens laevigata Wall. ex Hook.f. \& Thomson, Impatiens marianae Van Geert, Impatiens porrecta Wall. ex Hook.f. \& Thomson (Balsaminaceae), Litsea lancifolia (Roxb. ex Nees) Fern.-Vill.(Lauraceae), Musa sp. (Musaceae), Peliosanthes sp. (Asparagaceae), Phrynium pubinerve Blume (Marantaceae), Pseuderanthemum latifolium (Vahl) B.Hansen, Strobilanthes secunda T.Anderson (Acanthaceae), Stauranthera umbrosa (Griff.) C.B.Clarke (Gesneriaceae) and Steudnera assamica Hook.f. (Araceae). 
Table 1. Distinctive characters of Rhynchotechum nirijuliense, R. ellipticum and $R$. calycinum.

\begin{tabular}{llll}
\hline Character & $\boldsymbol{R}$. nirijuliense & R. ellipticum & R. calycinum \\
\hline $\begin{array}{l}\text { Petiole length } \\
\begin{array}{l}\text { Number of lateral } \\
\text { veins of leaves }\end{array}\end{array}$ & $0.5-1.2 \mathrm{~cm}$ & $1-4 \mathrm{~cm}$ & $5-6.5 \mathrm{~cm}$ \\
$\begin{array}{l}\text { Indumentum of } \\
\text { calyx lobes }\end{array}$ & Villous & $1-25$ & $14-15$ \\
$\begin{array}{l}\text { Style length } \\
\begin{array}{l}\text { Shape and size of } \\
\text { berry }\end{array}\end{array}$ & $\begin{array}{l}\text { Sharply ovoid, } \\
12-15 \times 8-10 \mathrm{~mm}\end{array}$ & $\begin{array}{l}\text { Widely ovoid, 3-4.5 } \\
\times 3-4.5 \mathrm{~mm}\end{array}$ & $\begin{array}{l}\text { Ellipsoid, 2.5-2.75 } \\
2-2.25 \mathrm{~mm}\end{array}$ \\
\hline
\end{tabular}

Phenology. Rhynchotechum nirijuliense flowers from April to May, fruiting is from May onwards.

Etymology. The specific epithet refers to the place where the new species was found.

Provisional IUCN conservation assessment. Despite several investigations throughout the whole district, only two populations with nearly 100 individuals each (total < 200, AOO $<5 \mathrm{~km}^{2}$ ) were found. With potential threats including human settlement and other development activities, the species could be assessed as Endangered (EN B2ab(iii), D) based on current data (IUCN Standards and Petitions Subcommittee, 2017). However, similar habitats exist in many other regions of the state and in view of the limited fieldwork presently possible, an assessment of Data Deficient (DD) may be a more suitable current assessment.

Additional specimens examined. INDIA: Arunachal Pradesh: Papum Pare district, Nirijuli,

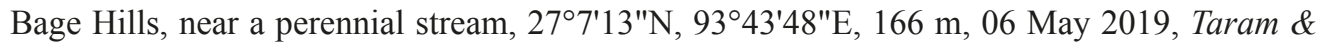
Borah 0169, 0170 (ASSAM)

Notes. Rhynchotechum is an Asian genus and half of the species are distributed in India (mostly Northeast India). Characters such as inflorescence size, style length and shape of the berries are very useful in the delimitation of species (Anderson \& Middleton, 2013). Apart from the new species described here, the other species of Rhynchotechum found in the state are $R$. ellipticum, R. calycinum, R. parviflorum, R. vestitum and R.obovatum.

ACKNOWLEDGEMENTS. The authors are thankful to B.M. Anderson and David Middleton for their help, cooperation, and comments on drafts of the manuscript. They also extend their thanks to the Department of Botany, Rajiv Gandhi University for providing necessary facilities for the study and Mr Ojar Taku for his help in the field. 


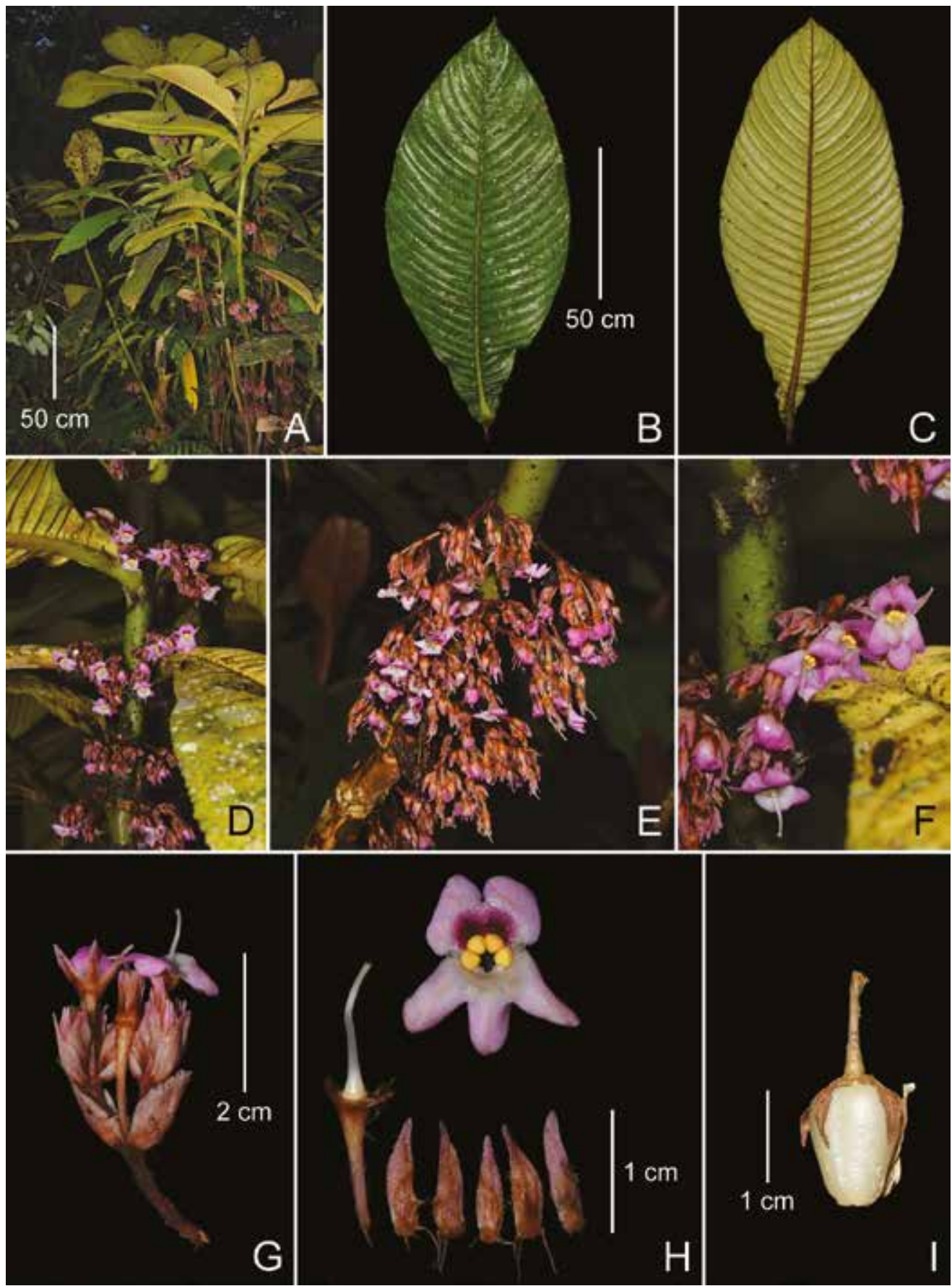

Fig. 1. Rhynchotechum nirijuliense Taram \& D.Borah. A. Habitat and habit. B. Adaxial surface of leaf. C. Abaxial surface of leaf. D-F. Inflorescences, showing the axillary arrangement of the cymes. G. Side view of a branch of the inflorescence. H. Dissected floral parts. I. Fruit. (Photos: D. Borah) 


\section{References}

Anderson, B.M. \& Middleton, D.J. (2013). A revision of Rhynchotechum Blume (Gesneriaceae). Edinburgh J. Bot. 70: 121-176.

IUCN Standards and Petitions Subcommittee (2017). Guidelines for Using the IUCN Red list Categories and Criteria. Version 13. Prepared by the Standards and Petitions Subcomittee.

Kayang, H. (2007). Tribal knowledge on wild edible plants of Meghalaya, Northeast India. Indian J. Tradit. Knowl. 6: 177-181.

Möller, M., Nampy, S., Janeesha, A.P. \& Weber, A. (2017). The Gesneriaceae of India: Consequences of updated generic concepts and new family classification. Rheedea 27 : 23-41.

Ozah, B. \& Borah, D. (2018). Nutritional Status and Traditional Food Practices of Karbi People Attached to Behali Reserve Forest, Assam. Int. J. Res. 5(4): 1921-1924.

Roy, S., Paul, T.K. \& Mukherjee, S.K. (2019). Taxonomic studies of the genus Rhynchotechum of Indian Part of Eastern Himalaya. In: Agnihotri, P. \& Khuraijam, J.S. (eds) Angiosperm Systematics: Recent trends and emerging issues. Dehradun: M/S Bishen Singh Mahendra Pal Singh, pp. 145-155.

Sinha, B.K. \& Datta, S. (2016). Taxonomic account on the family Gesneriaceae in Northeast India. Nelumbo 58: 1-43.

Taram, M., Mipun, P. \& Borah, D. (2020). Rhynchotechum parviflorum Blume (Gesneriaceae): a new record to mainland India. J. Threat. Taxa 12(1): 15208-15211. 
